\title{
Causality between Capital Flow, Human Capital Development and Economic Growth: A Case of Nigeria
}

\author{
Anuli Regina Ogbuagu ${ }^{1} \&$ Ebele Patricia Ifionu ${ }^{2}$ \\ ${ }^{1}$ Department of Economics and Development Studies, Federal University, Ndufu -Alike Ikwo, Ebonyi State, Nigeria \\ 2 Department of Finance and Banking, University of Port Harcourt, Rivers State, Nigeria \\ Correspondence: Anuli Regina Ogbuagu, Department of Economics and Development Studies, Federal University, \\ Ndufu -Alike Ikwo, Ebonyi State, Nigeria. E-mail: anulireg@gmail.com
}

Received: June 11, 2015

doi:10.5430/ijfr.v6n3p116
Accepted: July 6, 2015

Online Published: July 10, 2015

URL: http://dx.doi.org/10.5430/ijfr.v6n3p116

\begin{abstract}
This paper explored the impact of capital flow, human capital development on economic growth using annual time series data. To achieve our objectives; pairwise granger causality and dynamic autoregressive model was used. And we found no causality between capital flow (proxied by de jure and de facto measures of capital openness), human capital development (education expenditure and health expenditure) and economic growth. Again de jure (Deju) have a significant impact on economic growth. While foreign direct investment (fdin), foreign portfolio investment (pfin), credit to private sector (cpsn), external debt (debt), total education expenditure (exed), and total health expenditure (exht) have no significant impact on the growth rate.
\end{abstract}

Keywords: capital flow, human capital development, economic growth, investment, education

\section{Introduction}

One fundamental objective that is common to both developed and underdeveloped economies is how to attain and sustain economic growth. Nigeria is a middle income, mixed economy with an emerging market. The 2014 GDP rebasing revealed that Nigeria is the largest economy in Africa and has a track of becoming the $20^{\text {th }}$ largest economies in the world by 2020. Upon this impressive result, Nigeria faces an ongoing challenge achieving long sustained growth. Poverty and unemployment remain prominent among the major challenges facing the economy.

After the war in early seventies, it became prominent that Investment in capital is an important ingredient in the growth process and Countries lacking capital accumulation and technological progress usually grow much slower than countries with high investment rate and huge research and development expenditures (Oyejide, 2005). From early 1936 and mid 40s, researchers have continued to emphasize on the importance of capital investment among them are; Roy Horrod and Evsey Domar who developed a model of economic growth that emphasized on the importance of savings and productivity of capital, Its implications were that growth depends on the quantity of labour and capital; more investment leads to increased capital accumulation, which generates economic growth. Unfortunately less developed countries do not have sufficient incomes to enable sufficient rates of saving; therefore, accumulation of physical-capital stock through investment is low.

While Robert Solow and Trevor Swan in order to overcome the short coming in the Harod- Domar model developed an economic theory that accentuate how a steady economic growth rate will be accomplished using labor, capital and technology. The theory states that by varying the amounts of labor and capital in the production function, an equilibrium state can be accomplished. When a new technology becomes available, the labor and capital need to be adjusted to maintain growth. Here it becomes very obvious that technology change has a major influence on economic growth. On the other hand, the Solow-Swan model predicts that the income levels of poor countries will tend to catch up with or converge towards the income levels of rich countries if the poor countries have similar savings rates for both physical capital and human capital as a share of output, a process known as conditional convergence.

According to McKinnon (1973) financial Liberalization is necessary for investment and consequently for growth, because it leads to unified financial markets and the best strategy is to let interest rates freely fluctuate in order to remove all forms of repression. Yellen (2011) argues in favor of countries being open to financial flows, he said that 
countries that open their markets to capital flows can be expected to reap stronger economic growth. In addition, some observers argue that greater financial openness may even yield better macroeconomic policy, as countries are subject to the discipline of outside capital markets.

In support of capital liberalization, the Classical economic theorists predict that capital should flow from rich countries to poor countries, due to the effect of diminishing return of capital. Poor countries have lower levels of capital per worker - which explains, in part, why they are poor. But Lucas in his puzzles predicated that capital does not flow from developed countries to developing countries despite the fact that developing countries have lower levels of capital per worker. That is he emphasized on the reversal effect of capital flow (Lucas, 1988)

Researchers focusing on the explanation of the Lucas Paradox, tried to find the correlation between capital flow/ openness and economic growth. Several studies have found no correlation between openness and growth while some still insist on the positive benefits of capital flow in the developing countries.

Krugman (1993) concludes that policies that encourage financial integration do not spur long-run economic growth in developing countries. He argues that international financial integration is unlikely to be a major engine of economic development. He draws this conclusion after noting that (1) capital is relatively unimportant for economic development, and (2) large flows of capital from rich to poor countries have never occurred. This view suggests that a developing country that liberalizes international financial interactions is unlikely to boost domestic capital formation. Moreover, even if foreign funds substantially increase the domestic capital stock, this would ignite a depressingly small amount of long -run growth. Thus, Krugman disagrees with all of the building blocks of a traditional argument for international financial integration in developing countries. In line with the Krugman findings, authors like Rodrick (1998), Edison et al (2002), Bakare (2011), Kose et al (2009), found negative correlation between capital liberalization and economic growth.

Some authors have pointed to the quality of institutions as the key determinant of capital inflows to poorer nations. As evidence for the central role played by institutional stability, it has been shown that the amount of foreign direct investment a country receives is highly correlated to the strength of infrastructure, level of corruption, and the stability of government in that country and most importantly the state of human capital development. These accentuate the emphasis that capital flow alone cannot spur economic growth.

Addressing this issue, Arrow (1962), argued against the exogenous determinate of long run growth and formed the basis for endogenous model. Romer (1986), Lucas (1988), and Rebelo (1991) omitted technological change and came up with growth models that emphasizes indefinitely on investment in human capital, which had spillover effect on economy and reduces the diminishing return to capital accumulation. By broadening the concept of capital to include human capital, the new endogenous growth model argues that the law of diminishing-returns to-scale phenomenon may not be true as it is the case for East Asian economies. In simple terms, what this means is that if the firm which invests in capital also employs educated and skilled workers who are also healthy, then not only will the labour be productive but it will also be able to use the capital and technology more efficiently. In other words, technology and human capital development are both "endogenous" to the system (http://en.wikipedia.org/wiki/Endogenous_growth_theory)

The above underlines the importance of human capital investment as an agent of growth. Though, United Nation Development Programme (UNDP) (2013) has stated that Nigeria is not one of the African countries recording remarkable improvement in its human development index. In 2013, Nigeria was ranked among the low developed index at 153 out of 186 countries ranked.

Notwithstanding the poor human capital development, Nigeria in the bid to overcome stagnation, financial repression, external disequilibrium and achieve increase in foreign direct investment (capital flow), have adopted Structural Adjustment Programme (SAP) which Financial Liberalization, among other economic reform agenda is one of the key macroeconomic policy measures adopted with the aim of opening up the economy to overcome shortage of funds to meet investment and development needs. Also, the 2014 Economic Freedom Index has shown that Nigeria's economic freedom score is 54.3 percent, making its economy the $129^{\text {th }}$ freest in the 2014 index. Its score is 0.8 point lower than last year, reflecting decline in six of 10 economic freedoms variables including business freedom, Financial freedom, Monetary freedom, freedom from corruption, trade freedom, labour freedom and Investment freedom. Nigeria is ranked $26^{\text {th }}$ out of 46 countries in the Sub-Saharan African region, and its overall score is below the world average (http://www.heritage.org/index/country/nigeria).

Given the foregoing, the research questions are thus; (i) is there causality between capital flow liberalization, human capital development and economic growth; (ii) can capital flow in the absences of improved human development 
spur long-run economic growth.

It is the priorities of this study to empirically review the causality between capital flow liberalization, human capital development and economic growth in Nigeria, and secondly to examine the relationship between different component of capital flow, human capital development and economic growth.

Thus, the null hypotheses tested are;

$\mathrm{Ho}_{1}$ : There is no causality between dejure, defacto measure of capital flow liberalization, Human capital development and economic growth in Nigeria.

$\mathrm{Ho}_{2}$ : There is no significant long-run relationship between various components of capital flows, Human capital development and economic growth in Nigeria.

\section{Theoretical and Empirical Literature}

\subsection{Theories of International Investment}

Several attempts to provide the theoretical explanation for foreign investment have given rise to various schools of thought and theories. Several theories have been propounded to explain the reasons behind international investment. However there is no clear -cut theory on international capital flows especially in developing countries. We present brief outline of theories below;

\section{- Theory of Capital Movements}

This was propounded by the earliest theoreticians who assumed in the classical tradition, the existence of perfectly competitive market considered foreign investments as a form of factor movement to take advantage of the differential profit. The validity of this theory is clear from the observation by a known economist Charles Kindleberger that under perfect competition, foreign direct investment would occur and that it would be unlikely to occur in a world where the conditions were even approximately competitive.

\section{- Market Imperfections Theory}

This theory also known as the Monopolistic Advantage theory was expounded by Stephen in 1960. It is an important market imperfections approach to the explanation of foreign investments. The theory stated that foreign direct investment occurred largely in oligopolistic industries rather than in industries operating under near perfect competition. He suggested that the decision of a firm to invest in foreign markets was based on certain advantages the firm possessed over the local firms (in the foreign country), such as economies of scale, superior technology, or skills in the fields of management, production, marketing and finance.

\section{- Internalization Theory}

This is an extension of the market imperfections theory. It states that foreign investment results from the decision of a firm to internalize its specific advantages like superior knowledge (i.e. keeping the knowledge within the firm to maintain the competitive edge). Example, if a firm decides to externalize its knowhow by licensing a foreign firm, the firm (the authorising firm) does not make any foreign investment in this respect but, if it decides to internalize, it may invest abroad in production facilities.

\section{- Location Specific Advantage Theory}

This suggests that foreign investment is pulled by certain location specific advantages.

Hood and Young postulate four factors that are pertinent to location specific theory. They are: Labour Costs, Marketing factors (market size, market growth, stage of development and local competition), Trade barriers and Government policy. Other factors include cultural factors. It is important to note that it is the total cost and not only labour cost that is important.

\section{- International Product Life Cycle Theory}

This theory was developed by Raymond Vernon and Lewis T Wells in 1966. It describe how a firm tends to become Multinational at a certain stage in its growth. According to this theory, the production of a product shifts to different categories of countries through the different stages of the product life cycle.

The theory also shows that a new product is first manufactured and marketed in a developed country like the US (because of favourable factors like large domestic market entrepreneurship and ease of organising production). The product is then exported to other developed markets. As competition increases in these markets manufacturing facilities are established there to cater for these markets and also to export to the developing countries. As the product becomes standardised and competition increases, more manufacturing facilities are established in developing 
countries to lower production costs and due to some other reasons. The developed markets may possibly be serviced by exports from the production units in the developing countries.

\section{- The Eclectic Theory}

John Dunning has attempted to formulate a general theory of international production by combining the postulates of some of the theories. According to Dunning foreign investment by MNCs result from three comparative advantages which they enjoy, these include; the firm specific advantage; internalisation advantage and location specific advantages.

The internalisation advantage results from the ability of the firm to internalise its specific resources. Firm specific advantages result from the tangible and intangible resources held exclusively, at least temporarily, by the firm and which provide the firm comparative advantage over other firms. Even when a firm internalises its exclusive resources, it may not be able to serve a foreign market without foreign investment. Therefore, for production to take place on the foreign country there should be some location specific advantages. One important deficiency of the Eclectic theory is its inability to explain the foreign investment for acquisitions which have become a very important route to internalisation.

\subsection{Theories of Human Capital Investment}

\subsubsection{Endogenous Growth Theory}

In response to the various failures of the neoclassical model, Romer, Lucas, King and Rebelo, and other scholars have developed models in which steady growth can be generated endogenously - i.e., can occur without any exogenous technical progress -at rates that may depend upon taste and technology parameters and also tax policy.

Endogenous growth theory highlights the fact that if productivity is to increase, the labour force must continuously be provided with more resources. Resources in this case include physical capital, human capital, and knowledge.

Growth is therefore driven by accumulation of factors of production, while accumulation in turn is the result of investment in the private sector. This implies that the only way a government can affect economic growth, at least in the long run, is through its impact on investments in capital, education and research and development.

The AK Growth Model proposed by Rebelo (1991) results from setting $\alpha=0$ in the neoclassical equation $\mathrm{y}=\mathrm{Ak}^{\alpha}$ (equation 1$)$ :

$$
\mathrm{y}=\mathrm{Ak}
$$

Where $\mathrm{k}=\mathrm{K} / \mathrm{L}$ as before, but $\mathrm{K}$ now is interpreted as a broad measure of capital -composite measure of both physical and human capital stock. A is a parameter that captures factors affecting the level of technology

Using the capital accumulation equation (2), the steady- state growth rate of the capital stock per worker can be shown to be equal to

$$
\mathrm{g}_{\mathrm{k}=} s_{A}-(\eta+\delta)
$$

With the steady- state growth rate per capita given by

$$
\mathrm{g}_{\mathrm{y}}=\mathrm{s}_{\mathrm{A}}-(\eta+\delta)
$$

This means that growth rate is, for $\mathrm{sA}>\mathrm{n}+\delta$, positive (and constant over time) and that the level of income per capita rises without bound.

An important implication of the AK model is that in contrast to the neoclassical model, an increase in the saving rate permanently raises growth rate per capita. In addition and in contrast with the neoclassical growth model, which predicts that poor countries should grow faster than rich countries -AK model implies that poor nations whose production process is characterized by the same degree of technological sophistication as other nations always grow at the same rate as rich countries regardless of initial level of income.

Rebelo's analysis demonstrates that to obtain positive endogenous steady growth requires only the existence of a subset of capital goods whose production takes place under constant returns to scale and does not require the use of non-reproducible inputs. These externalities imply that the competitive equilibrium growth path does not coincide with that which could be achieved in an optimally planned economy.

The latter conclusion was reached by virtually all the theoretical analyses based upon successive formulations that belong to the family of "endogenous growth models". It carries the implication that growth performance might be improved by public policy action. 
Lucas (1988), Human Capital Model is one of the best- known attempts to incorporate spillover effects of human capital accumulation. The model is built upon the idea that individual workers are more productive, regardless of their skill level, if other workers have more human capital.

A simplified presentation of the model is as follows. Human capital is accumulated through explicit "production": a part of individuals' working time is devoted to accumulation of skills.

Formally, let k denote physical capital per worker and h human capital per worker or generally, "knowledge" capital. The production process is specified as follows

$$
\mathrm{y}=\mathrm{Ak}^{\sigma}[\mu(\mathrm{h})]^{1-\sigma}, \quad 0<\mu<1
$$

Where, $u$ denotes the fraction of time that individuals devote to producing goods.

The growth of physical capital depends on the saving rate ( $\mathrm{I}=\mathrm{sy}$ ), while the growth rate of human capital is determined by the amount of time devoted to its production:

$$
\frac{\mathrm{h}^{\prime}}{\mathrm{h}}=\alpha(1-\mu), \quad \alpha>0
$$

This means that the long- run growth rate of both capital and output per worker is $\propto(1-\mu)$. The rate of human capital growth and the ratio of physical capital to human capital converge to a constant. In the long- run, the level of income is proportional to the economy's initial stock of human capital. The savings rate has no effect on the growth rate.

The important implication of Lucas (1988) model is that under a purely competitive equilibrium its presence leads to an underinvestment in human capital accumulation because private agents do not take into account the benefits of human capital accumulation. The equilibrium growth rate is smaller than the optimal growth rate, due the existence of externalities. Because the equilibrium growth rate depends on the rate of investment in human capital, the externality implies that growth would be higher with more investment in human capital. In conclusion, government policies are necessary to increase the equilibrium growth rate up to the level of optimal growth rate. This implies that a government subsidy to human capital formation or schooling could potentially result in a substantial increase in the rate of economic growth.

\subsection{Empirical Literature}

A number of studies have examined empirically the growth enhancing effects of capital flows liberalization and the results of these studies have been mixed, some found positive effect while others have found little or no effect on growth.

Below are some of these studies on the relationship between economic growth and financial liberalization.

\subsubsection{Studies That Support Positive Relationship between Financial Liberalization and Economic Growth}

Klein and Olivei (1999) find a positive effect of capital account liberalization on growth among industrial countries, but they do not find evidence that capital account liberalization promotes growth in non industrial countries. This study follows a slightly different strategy than other research in this area by first focusing on the role of capital account liberalization on financial development and then considering the effect of financial development on growth. Klein and Olivei regress the change in financial depth on the capital account liberalization indicator Share described above (along with other standard regressors) over the period 1986 to 1995 . They find a significant effect of capital account liberalization on the change in financial depth in the cross section of 82 developed and developing nations. Klein and Olivei show that capital account liberalization significantly affects the change in financial depth in a sample consisting of the 20 OECD countries but not in a sample of the non-OECD countries, nor in a narrower non-OECD sample of 18 Latin American countries, a group that had a relatively high incidence of capital account liberalizations. They also estimated a growth model that includes the change in financial depth as regressor and find that financial development is a significant determinant of growth per capita. They conclude that the beneficial effects of capital account liberalization, at least with respect to promoting financial depth, are achieved only in an environment where there is a constellation of other institutions that can usefully support the changes brought about by the free flow of capital. While Easterly (2000), assess whether international financial liberalization can accelerate economic growth, by improving the functioning of domestic financial markets and bank. The analysis suggests that the answer is "positive." First, liberalizing restrictions on international portfolio flows tends to enhance stock market liquidity. In turn, enhanced stock market liquidity accelerates economic growth primarily by boosting productivity growth. Secondly, allowing greater foreign bank presence tends to enhance the efficiency of the domestic banking system. In turn, better-developed 
banks spur economic growth primarily by accelerating productivity growth. Thus, international financial integration can promote economic development by encouraging improvements in the domestic financial system. She argues that the average growth rate among developing countries remained stable at a relatively low level during the 1990s in spite of the boom in capital flows. On the other hand faster rate of growth has been associated with high capital flows in more advanced middle income countries. This shows that the impact of capital inflows varies in countries and regions of the world depending on the prevailing economic conditions.

Bekaert, Harvey, and Lundblad (2001), examine the impact of stock market liberalization on economic growth. As previous researchers have done, they begin their analysis by augmenting the standard set of growth model variables with their variable indicating stock market liberalization. To maximize the time-series content in their regression, they use a moving average panel data method. In general, they find that financial liberalization leads to a 1 percent increase in annual per capita GDP growth over a five-year period and that this effect is statistically significant. Klein (2003) provides evidence that capital account openness significantly contributes to growth among middle-income countries but not among poor countries or the richest countries. Klein allows for a quadratic interaction between initial income and indicators of capital account openness and thus nests the specification of Arteta, Eichengreen, and Wyplosz, (2001) as well as a quadratic interaction between indicators of government quality (which are highly correlated with income) and indicators of capital account openness. The finding that middle-income countries systematically benefit from capital inflows is consistent with the view of Rodrik (1998) that countries require adequate institutions, regulatory policies, and supervisory agencies to benefit from capital flows.

Edison et.al (2004), following, Klein (2003), used a specification in which there is a quadratic interaction between income per capita and capital account openness or stock market liberalization and demonstrate that there is a positive and significant effect of capital account openness and stock market liberalization on economic growth for middle income countries but not for poor or rich countries. This result according to them is consistent with view that poorer countries do not have the legal, social, and political institutions necessary to fully enjoy the benefits of capital account liberalization. Obstfeld, (2007) argues that despite meager evidence that developing countries gain from financial globalization, they should proceed cautiously, in an incremental manner. He maintains that there is strong evidence that domestic financial development spurs growth under the right conditions, and the conditions - plus domestic financial development itself are likely to make capital inflows from abroad more productive. Asamoah (2008) assessed financial liberalization and its impact on savings, investment and the growth of GDP in Ghana. The data used included monthly savings and interest rates and also yearly and seasonal dummy variables instead of post and pre-liberalization as the dummies. The empirical estimation of 42 observations i.e. January 2000 to June 2003 was evaluated using the Ordinary Least Square (OLS) regression analysis. The results show that the rise in interest rate over the years after liberalization of the financial sector has led to a corresponding increase in savings which has a positive impact on the growth of GDP. The findings showed that financial liberalization has increased the rate of capital accumulation and improved efficiency in capital utilization which is both essential for economic growth.

Kose et al. (2009) analyzed the relationship between financial openness and productivity growth using an extensive data set that includes various measures of productivity and financial openness for 67 countries -21 industrialised and 46 developing countries. They distinguished between de jure capital account openness- the absence of restrictions on capital account transactions and de facto financial integration- measured stocks of foreign assets and liabilities relative to GDP and they find that economies with more open capital accounts generally have higher TFP growth even after controlling for the standard determinants of growth. They further disaggregated the financial integration measure into stocks of liabilities attributable to different types of capital flows and they find strong evidence that FDI and Portfolio equity flows boost TFP growth while debt is negatively correlated with GDP growth.

Qazi (2013), explore the link between financial liberalization index (FLI) and economic growth in Pakistan by using annual data for 1971- 2007. The Phillips Perron unit root test is utilized to verify the level of integration and Auto-Regressive Distributed Lag (ARDL) technique for obtaining long run and short run coefficients. The empirical finding indicates that financial liberalization (FLI) and economic growth are positively linked in the short run. On the other hand, FLI is statistically insignificant in the long run, while the impact of real interest rate (RIR) on economic growth is negative and significant. This means that one unit increase in the RIR causes GDP to decline by Rs. 1.03 million. Our investigation recommends that SBP and the GOP should pursue financial liberalization policies that are consistent with economic growth. Adam (2011) investigated the impact of Ghana's financial openness induced growth on poverty using the Johansen Co-integration test and Granger-Causality tests. The study was limited to the period from 1970 to 2007. Annual Standard of Living Index (SLI) was proxied for poverty and the financial liberalization index was constructed using Principal Component Analysis (PCA). The results showed that there is a positive relationship between growth and standard of living, though it is disproportionate. Also, it provides evidence that there 
exist a positive long-run relationship between growth and financial liberalization. This means that Ghana's financial liberalization has contributed positively towards its economic growth.

\subsubsection{Studies That Found No Correlation between Openness to Capital Flow and Growth}

Krugman (1993) concludes that policies that encourage financial integration do not spur long-run economic growth in developing countries. He argues that international financial integration is unlikely to be a major engine of economic development. He draws this conclusion after noting that (1) capital is relatively unimportant for economic development, and (2) large flows of capital from rich to poor countries have never occurred. This view suggests that a developing country that liberalizes international financial interactions is unlikely to boost domestic capital formation. Moreover, even if foreign funds substantially increase the domestic capital stock, this would ignite a depressingly small amount of long -run growth. Thus, Krugman disagrees with all of the building blocks of a traditional argument for international financial integration in developing countries. Rodrik (1998), in a widely cited paper, also casts doubt on the effect of capital account liberalization on growth. In a sample that includes almost 100 countries, developing as well as developed, he finds no significant effect of capital account liberalization, as measured by Share, on the percentage change in real income per capita over the period 1975 to 1989 in growth regressions that also include initial per capita income, initial secondary-school enrolment rate, an index of the quality of governmental institutions, and regional dummy variables. Likewise, he finds no relationship between capital account liberalization and investment-to-income, or between capital account liberalization and inflation. Edison et al (2002) also find little evidence of a relationship between capital account liberalization and growth. Using a variety of econometric techniques and a new data set focusing on quantitative measures rather than rule- based measures, they find that financial integration does not accelerate economic growth per se, even when controlling for particular economic, financial, institutional, and policy characteristics. They do, however, find that international financial integration is positively associated with real per capita GDP, educational attainment, banking sector development, stock market development, the law-and-order tradition of the country, and government integrity (low levels of government corruption. And Bakare (2011) using time series data and OLS multiple regression analytical method and focusing on qualitative measure find a significant and negative relationship between financial sector liberalization and economic growth in Nigeria.

Empirical studies of the Lucas paradox typically show how relaxing one (or several) assumptions of the basic neoclassical model helps explain capital flows from rich to poor countries. Differences in human capital (Lucas, 1990), in the risk of sovereign default (Reinhart and Rogoff, 2004), in capacity to use technologies (Eichengreen, 2003), and in institutional quality (Alfaro et al., 2008) seem to be relevant for the direction of cross-border net capital flows. The emphasis on institutional quality is the natural consequence of a body of work showing that social infrastructure, which includes government policies and institutional structure and some specific institutional characteristics, such as the protection against the risks of expropriation (Acemoglu and Johnson, 2005), have first order effects on long-run economic performance by affecting investment and total factor productivity. Obstfeld and Taylor (2005) showed that during the 1990s, net capital flows to poor countries remained relatively small, while gross capital flows, in general, were large, in particular among advanced economies. This, they argued, was evidence that portfolio diversification, not development finance, was the main factor driving financial integration.

The results of the empirical literature reviewed above indicate that there is a wide divergence in results across studies. This reflected a number of differences in these studies. Liberalization of capital flows can benefit both source and recipient countries by improving resource allocation, reducing financing costs, increasing competition and accelerating the development of domestic financial systems. The empirical evidence, however, is mixed on the benefits, and it suggests that countries benefit most when they meet certain thresholds related to institutional and financial development. The principal cost of capital flow liberalization stems from the economic instability brought on by volatile capital flows. In extreme cases, sudden stops or reversals in capital inflows can trigger financial crises followed by prolonged periods of weak growth.

\subsubsection{Studies on Relationship between Human Capital Development and Economic Growth}

Many developing countries have made significant progress in ensuring better access to education as evidenced by improved literacy and enrollment rates and higher quality and more equitable distribution of education services. But the returns from the investment in education vary a great ideal. Thomas and Wang (1996) have argued that education alone is not a guarantee for sustainable economic growth. They observed that Sri Lanka had higher per capital income than the Republic of Korea in the 1960s and its social indicators outstripped those in many low- income countries. But its income growth rate stagnated in the 1970s and 1980s. Similarly, for some time, East Asia has scored high both in the importance people attach to basic education (the demand side) and its broad availability (the 
supply side). But the financial crisis of the 1990s has exposed the need for East Asian countries to restructure their economies and upgrade the supply of high - skilled labour and their regulatory capacity.

Easterly (1997), after analyzing data from 146 countries in which Nigeria is one could not find any significant relationship between investment in physical capital and GDP growth. In fact the coefficients for 71 countries including Nigeria were negative. And this findings support the modern growth theories that there is an endogenous component to the growth nexus, which is grossly underdeveloped in developing countries. In modern thinking, investment is thought of in the context of accumulation of both physical and human capital.

A number of other empirical studies have shown a strong linkage between education and economic growth. Education has been observed to substantially increase farm productivity in Korea, Malaysia and Thailand (World Bank 1990)) showed that massive investment in primary and secondary education significantly explained the development miracle experienced in south East Asian.

China experienced the most rapid growth of any large country in any part of the world during its period of economic reform. In less than two decades, it achieved what it took other countries to accomplish in centuries. It's per capital income doubled between 1978 and 1987 and then doubled again between 1987 and 1996(World Bank 1997). Over 170 million of the 270 million

Chinese living in absolute poverty in 1978 were raised above the poverty threshold. China went from lack- luster growth of $3.9 \%$ before the reforms to 8 to $9.5 \%$ after the reforms.

However, studies have shown that significant share of Chinaecs growth could be explained by the accumulation of human capital (see World Bank, 1997).

Odusola (1997) using time series data on Nigeria arrived at a result, which suggests significant butt weak linkages between the levels of government capital investment in education and real income per working age person. He found no significant relationship between the level of government recurrent expenditure on education and real per capita income. For investment in education to affect real growth, the increase in human capital formation resulting from increased educational investment must be translated into increased productivity through an efficient labour market, which adequately rewards investments in human capital. The new emphasis on the role of human capital development in economic growth led to the accumulation of empirical literature that focused on the estimation of returns to schooling at various levels of education. Arrow (1962) pioneered a work that considered the impact of human capital on growth and concluded that variation in investment performance and growth variations in accumulation of human capital aids growth. In 1996, Jones carried out a study on human capital ideas and economic growth and strongly emphasized on investment on education and its attainment as a source of economic growth.

The effects of health on economic performance are usually discussed at both the micro and macro levels in the literature. Evidence of this link at the micro level has been discussed extensively elsewhere (see Schultz, 2002). Good health is a necessary condition for school attendance since a child has to be healthy to endure the rigours of schooling. Also, healthier students, in contrast to their less healthy counterparts, have lower malingering and higher cognitive functioning, and thus receive a better education for a given level of schooling which in turn guarantees higher earning over a longer period of time. Sound health enhances workerse productivity through the spill-over effects on their physical and mental abilities. All other things being equal, it is presumed that healthy workers work harder and longer and reason more plainly than those who are less gifted with good health. Good health can also minimize the incidence of poverty through higher labour participation and reduction in cost of medical services, thus releasing income for other welfare improving consumption. This condition holds irrespective of whether the worker is skilled or unskilled.

Drawing our strength from the existing literature, there is a dearth of study on these issues in Nigeria, and this is the gap the paper is set to fill.

\section{Model Specification}

There are various theoretical models that have been used to explain the relationship between liberalization and economic growth. This study adopts a theoretical framework in which the linkage between capital inflows and economic growth is highlighted. In the framework, the relationship between capital inflows and growth is based on a simple endogenous growth model. The relationship between capital inflows and growth is examined with an endogenous growth model of the AK type, in which the effects of changes in financial variables on steady- state growth is brought about through the impact of capital accumulation.

In a closed- economy version of the AK model, aggregate production is given by: 


$$
\mathrm{Y}_{\mathrm{t}}=\mathrm{Ak}_{\mathrm{t}}
$$

Where, output is a linear function of the aggregate capital stock. This type of production function can be viewed as a reduced form for either a framework in which the economy is competitive with external economies, as illustrated by Romer (1989), or a situation in which $\mathrm{k}_{\mathrm{t}}$ is assumed to be a composite of physical and human capital as in Lucas (1988), where the two types of capital are reproducible with identical technologies. In the model, there is no population growth and only one good is produced in the economy, which can either be consumed or invested. Assuming that capital stock depreciates at a rate of $\delta$ per period, and then gross investment equals

$$
\mathrm{I}_{\mathrm{t}}=\mathrm{k}_{\mathrm{t}-1}-(1-\delta) \mathrm{k}_{\mathrm{t}}
$$

The theoretical framework in previous section allows for reduced form of the AK type endogenous - growth model, in which the rate of growth of the economy is endogenously determined by net financial flows and financial development. The specification of the growth equation is closely related to that of Mankiw, Romer, and Weil (1992).

Following Soto (2000) and Senhadji (2000), the empirical model is specified as

$$
\text { RGDP }=\mathrm{f}(\text { FOPEN, FFLOWS, PHY, DET) }
$$

Where RGDP is the natural log of real per capita GDP, FOPEN is a vector measure of financial openness, FFLOWS represents different components of capital inflows, PHY is the human capital indicator and DET is vector of growth determinants (control variables).

For empirical analysis, we will therefore modify equation (7) and restate the growth model as

$$
\mathrm{y}_{\mathrm{t}}=\alpha_{0}-\lambda \mathrm{V}_{\mathrm{t}}+\beta \mathrm{F}_{\mathrm{t}}+\varnothing \mathrm{X}_{\mathrm{t}}+\varepsilon_{\mathrm{t}}
$$

Where $\mathrm{y}=$ real gross domestic product per capita growth, $\alpha_{0}$ is a constant, $\mathrm{V}$ is a measure of financial openness, $\mathrm{F}$ is a composition of different components of capital flows which for this study comprise of foreign direct investment, foreign portfolio investment and debt flows, $\mathrm{P}$ is variable that represent human capital development, $\mathrm{X}$ is a vector of growth control variables, for this study we include only institutional quality, $t$ is time period, $\alpha, \lambda, \beta, \varnothing$ are parameters to be estimated, and $\varepsilon$ is error term.

\section{To achieve objective 1}

To be more precise we therefore expand the above model to include all our variables;

$$
\operatorname{Rgdp}_{\mathrm{t}}=\beta_{0}+\beta_{1} \text { deju }_{\mathrm{t}}+\beta_{2} \text { defa }_{\mathrm{t}}+\beta_{3} \text { exed }_{\mathrm{t}}+\beta_{4} \text { exht }_{\mathrm{t}}
$$

Rgdp (real gross domestic product) represents economic growth, deju signify de jure measure of financial openness, defa represent de facto measure of capital flow, total expenditure in education stands for (exed), and (exht) represents total expenditure in health sector;

\section{To achieve objective 2}

$$
\operatorname{Rgdp}_{t}=\beta_{0}+\beta_{1} \operatorname{deju}_{t}+\beta_{2} \text { fdin }_{t}+\beta_{3} \text { cpsn }+\beta_{4} \text { debt }+\beta_{5} \text { exed }_{t}+\beta_{5} \text { exht }+\beta_{7} \text { insq }_{t}
$$

In the model presented above, Rgdp represents economic growth, deju is the capital account openness, fdin equals foreign direct investment, fpin is foreign portfolio investment, debt represent external debt, exed --measures expenditure in education, exht stands for expenditure in health while insq represents institutional quality.

\subsection{Measurement of Variables Used in Estimation}

\section{- Economic Growth:}

To measure Economic Growth, we used data on Nigeria's Real Gross Domestic Product Per Capita available from Central Bank of Nigeria Statistical Bulletin 2012.

\section{- Financial Openness:}

To measure financial openness, we followed Kose et al, (2008) and employ both de jure and de facto measures.Our benchmark measure of de jure capital account openness is the Chinn- Ito index (KAOPEN) which measures degree of capital account openness. The dataset encompasses the time period 1970- 2009 for 182 countries;

\section{a. De Jure Measures}

The IMF's Annual Report on Exchange Arrangements and Exchange Restrictions (AREAER) provides the most readily available, standardized source of information. Available since 1967, the AREAER provides a list of the rules and regulations governing resident and non- resident capital account transactions in each country, a table that summarizes the presence of restrictions, and a qualitative judgment on whether the country has an open or closed 
capital account.

\section{b. Defacto Measures}

Our benchmark measure of de facto financial integration is the ratio of gross stocks of external liabilities (FDI + FPI + Debt) to GDP - cumulated measure of inflows that is most closely related to the notion of openness to foreign capital that could be associated with technological and other spill-over. This measure is primary from Lane and Milesi - Ferretti's (2006) External wealth of Nations Database.

\section{- Institutional quality:}

It is well known that institutions matter a great deal for economic performance. Following Chantel et al (2006) and Raschky et al (2009), we use the type of political regime in a country- democratic or autocratic as our proxy for institutional quality. We use the polity IV database and this variable takes the value -10 for fully institutionalized autocratic regimes and 10 for fully institutionalized democratic regimes with special values of -66 (interruption), -77 (interregnum), -88 (transition) and 99 (independence).

\section{- Human capital development measurement}

The conventional standard to measure human capital stock has been largely categorized into three parts; output, cost, and income based approach.

Some economists attempt to measure the stock of human capital utilizing school enrollment rates as a proxy of human capital (Baro and Lee 1993).

Nahru, Swanson and Dubey (1993) attempted to measure relationship between human capital and students, "accumulated years of schooling in the employable age as educational attainment. It is difficult to clearly demonstrate this relationship because educational attainment is a part of regular (school) education.

Romer (1999) used skilled adults and total adults to measure the stock of human capital in the national economy (eg. OECD utilized International Adult Literacy Survey (IALS), the ratio between literacy adults and total adults. While some researchers also have used cost based approaches in measuring the stock of human capital through summing costs investment for one's human capital. Others have also used income-based approach based on the returns which an individual obtains from labour market throughout education investment. Hanson (2008) shows OECD measure on human capital is closely linked to international comparable statistics considering investment in human capital, quality adjustment and result of education.

The conventional measurements also include investment in human capital focused on the current level of human capital investment within a national boundary. But the United Nation Development Programme (UNDP), has reported Human Development Index (HDI) to constitute; health, knowledge, and standard of living with many subvariables such as life expectancy at birth, expenditures in school and health sector, adult literacy rates, school enrollment ratio and GDP per capita.

\subsection{Sources of Data}

These data sources include the central Bank of Nigeria's publications (Statistical Bulletin, and annual reports and statement of Accounts 2012), Annual Abstract of statistics of the National Bureau of statistics, World Bank publications (World Development Finance) and finally, External wealth of Nations Database.

\subsection{Method of Data Analyses and Time Series Property of Data Used}

The methodology applied in this study following the literature is based on time series data sets. The estimation procedure adopted in deriving the estimates of the parameters of economic relationships is the Ordinary Least Squares (OLS).

\section{i. Unit-Root Test:}

There often exists the problem of non-stationarity in empirical research involving time series data and this renders the traditional tools of econometrics (like OLS) inappropriate. To overcome this unit-root problem, we test for stationarity of the series in use. The Augmented Dickey-Fuller test (ADF) is of choice in this study because of its efficiency in detecting unit root. It is specified as follows:

$$
\Delta Y_{t}=\theta_{o}+\theta_{1} Y_{t-1}+\sum_{i=1}^{k} b_{i} \Delta Y_{t}-{ }_{i}+\mu t_{t}
$$


Where, $Y_{t}$ is a vector of all variables in the model $\theta_{i}$ and $b_{i}$ are parameters of the model, $\mu_{t}$ is thewhite noise at time while $k$ and $\Delta$ remain as defined in equation (10) above. This we will achieve, conducting the test by first or second level difference if the series are integrated of order one or order two (i.e. I(1) or I(2)). The null hypothesis here is that $Y_{t}$ has a unit root (that is, non-stationary) and the alternative is that there is no unit root (that is, stationary). If the variables turn out to contain unit roots, we will therefore, conclude that they are non-stationary.

\section{- To achieve objective 1, Pairwise Granger Causality Tests was performed;}

We test for the absence of Granger Causality by estimating the following VAR model;

$$
\begin{gathered}
Y_{t}=a_{o}+a_{1} Y_{t-1}+\ldots+a_{p} Y_{t-p}+b_{1} X_{t-I}+\ldots+b_{p} X_{t-p}+Y_{t} \\
X_{t}=C_{o}+C_{1} X_{t-1}+\ldots+C_{p} X_{t-p}+d_{1} Y_{t-1}+\ldots+d_{p} Y_{t-p}+V_{t}
\end{gathered}
$$

Testing $\mathrm{H}_{\mathrm{o}}: \mathrm{b}_{1}=\mathrm{b}_{2}=\ldots . \mathrm{b}_{\mathrm{p}}=0$

Against $\mathrm{H}_{1}$ : Not $\mathrm{H}_{0}$

Is a test that $\mathrm{X}_{\mathrm{t}}$ does not granger cause $\mathrm{Y}_{\mathrm{t}}$.

Similarly, testing $\mathrm{H}_{\mathrm{o}}: \mathrm{d}_{1}=\mathrm{d}_{2}=\ldots \mathrm{d}_{\mathrm{p}}=0$ against

Against $\mathrm{H}_{1}$ : Not $\mathrm{H}_{0}$ is a test that $\mathrm{Y}_{\mathrm{t} \text {. }}$ does not granger cause $\mathrm{X}_{\mathrm{t}}$

In each case a rejection of the null hypothesis implies that there is Granger Causality between the variables.

In testing for granger causality, two variables are usually analyzed together, while testing for their interaction. All the possible results of the analyses are four.

$>$ Unidirectional granger causality from variable $Y_{t}$ to variable $X_{t}$

$>$ Unidirectional granger causality from variable $\mathrm{X}_{\mathrm{t}}$ to variable $\mathrm{Y}_{\mathrm{t}}$

$>\mathrm{Bi}$ - directional causality and

$>$ No causality.

\section{- To achieve Objective 2, Dynamic Auto regression Analysis was;}

Autoregressive processes arise frequently in econometrics. For example, we might have a simple dynamic model of the form:

$$
\mathrm{y}_{\mathrm{t}}=\beta_{0}+\beta_{1} \mathrm{y}_{\mathrm{t}-1}+\varepsilon_{\mathrm{t}} ; \varepsilon_{\mathrm{t}} \sim \text { i.i.d. }\left[0, \sigma^{2}\right]
$$

To achieve our objective we used a simple dynamic model of the above form, where the dependent variable is regressing itself in lags.

\section{Results}

\subsection{Unit Root Test}

As indicated in the literature, most time series variables are non-stationary and using non-stationary variables in the model might lead to spurious regressions. The first or second differenced terms of the most variables will usually be stationary. Hence some of the variables were found significant at level while all are significant at first difference except Fdin and Cpsn which is significant at second difference.

To achieve our objective 1, the pairwise granger causality analysis was performed and the result is presented in the table below; 
Table 1. Pairwise Granger Causality Tests

\begin{tabular}{|c|c|c|c|}
\hline Null Hypothesis: & F-Statistic & Probability & Decision \\
\hline DEJU does not Granger Cause RGDP & 1.93715 & 0.17645 & \\
\hline RGDP does not Granger Cause DEJU & 0.15641 & 0.85650 & No Causality \\
\hline DEFA does not Granger Cause RGDP & 0.53623 & 0.59510 & \\
\hline RGDP does not Granger Cause DEFA & 0.59737 & 0.56208 & No Causality \\
\hline EXED does not Granger Cause RGDP & 0.22201 & 0.80334 & \\
\hline RGDP does not Granger Cause EXED & 0.19176 & 0.82737 & No Causality \\
\hline EXHT does not Granger Cause RGDP & 0.58500 & 0.52859 & \\
\hline RGDP does not Granger Cause EXHT & 1.75936 & 0.20387 & No Causality \\
\hline DEFA does not Granger Cause DEJU & 3.07512 & 0.07412 & \\
\hline DEJU does not Granger Cause DEFA & 1.91358 & 0.17984 & No Causality \\
\hline EXED does not Granger Cause DEJU & 4.55206 & 0.02723 & \\
\hline DEJU does not Granger Cause EXED & 1.66065 & 0.22114 & Uni-causality \\
\hline EXHT does not Granger Cause DEJU & 2.22274 & 0.14066 & \\
\hline DEJU does not Granger Cause EXHT & 1.88818 & 0.18356 & No causality \\
\hline EXED does not Granger Cause DEFA & 0.44296 & 0.64977 & \\
\hline DEFA does not Granger Cause EXED & 4.13338 & 0.03572 & Uni-causality \\
\hline EXHT does not Granger Cause DEFA & 4.77743 & 0.02361 & \\
\hline DEFA does not Granger Cause EXHT & 3.24032 & 0.06584 & Uni-causality \\
\hline EXHT does not Granger Cause EXED & 12.1087 & 0.00063 & \\
\hline EXED does not Granger Cause EXHT & 1.90760 & 0.18071 & Uni-causality \\
\hline
\end{tabular}

Source; own computation (E-view), 2015

From the above result there is no causality between the independent variables (deju, defa, exed, exht) and rgdp. Rather there exists uni-causality between education expenditure (exed) and dejure (deju), de facto (defa) and health expenditure (exht), and health expenditure (exht) and education expenditure (exed).

The above result concur with the Pairwise Correlation Matrix presented in the table below

Table 2. Pairwise Correlation Matrix

\begin{tabular}{lccccc}
\hline & RGDP & DEJU & DEFA & EXED & EXHT \\
RGDP & 1.000000 & 0.497673 & -0.359190 & -0.283101 & -0.369648 \\
DEJU & 0.497673 & 1.000000 & -0.754901 & -0.606387 & -0.521990 \\
DEFA & -0.359190 & -0.754901 & 1.000000 & 0.910234 & 0.542900 \\
EXED & -0.283101 & -0.606387 & 0.910234 & 1.000000 & 0.265334 \\
EXHT & -0.369648 & -0.521990 & 0.542900 & 0.265334 & 1.000000 \\
\hline
\end{tabular}

Source; own computation (E-view), 2015

From the result in Table 2, it is evident that there is poor correlation existing between the dependent variable (rgdp) and the independent variable (deju, defa, exed, exht).

To achieve objective 2; Simple auto regressive model was used and the result is presented below; 
Table 3. Auto Regressive Model

Dependent Variable: D(RGDP)

\begin{tabular}{crlrr}
\hline \hline Variable & Coefficient & Std. Error & t-Statistic & Prob. \\
\hline C & 0.757170 & 0.356437 & 2.124276 & 0.0596 \\
RGDP(-1) & -0.337442 & 0.211138 & -1.598206 & 0.1411 \\
RGDP(-2) & -0.054052 & 0.088747 & -0.609054 & 0.5561 \\
D(DEJU) & 1.942390 & 0.894511 & 2.171454 & 0.0550 \\
D(D(FDIN)) & $-1.37 \mathrm{E}-06$ & $1.62 \mathrm{E}-06$ & -0.847638 & 0.4165 \\
D(PFIN) & $2.18 \mathrm{E}-08$ & $5.44 \mathrm{E}-07$ & 0.040173 & 0.9687 \\
D(D(CPSN)) & $-9.56 \mathrm{E}-08$ & $1.04 \mathrm{E}-07$ & -0.915904 & 0.3813 \\
D(DEBT) & $1.64 \mathrm{E}-07$ & $4.25 \mathrm{E}-07$ & 0.385454 & 0.7080 \\
D(EXED) & $-1.18 \mathrm{E}-05$ & $5.96 \mathrm{E}-06$ & -1.987254 & 0.0750 \\
D(EXHT) & $-6.67 \mathrm{E}-06$ & $5.61 \mathrm{E}-06$ & -1.188971 & 0.2619 \\
D(INSQ) & 0.007225 & 0.014574 & 0.495779 & 0.6308 \\
\hline \hline R-squared & 0.539628 & Mean dependent var & -0.005239 \\
Adjusted R-squared & 0.079257 & S.D. dependent var & 1.085619 \\
S.E. of regression & 1.041710 & Akaike info criterion & 3.225286 \\
Sum squared resid & 10.85160 & Schwarz criterion & 3.772417 \\
Log likelihood & -22.86550 & F-statistic & 1.172159 \\
Durbin-Watson stat & 2.240528 & Prob(F-statistic) & 0.403289 \\
\hline \hline
\end{tabular}

Source; own computation, e-view 2015.

From the above result, it is clear that rgdp in lag $1 \& 2$ have no impact in the current growth level.

And this is against our apriori expectation. Deju which is a measure of capital account openness is significant with the probability value of 0.0550 . While foreign direct investment (fdin), foreign portfolio investment (pfin), credit to private sector (cpsn) external debt (debt), total education expenditure (exed), and total health expenditure (exht) have no significant impact on the growth rate.

\subsection{Policy Implication}

The poor causality between the de jure and de facto measure of financial openness and growth could be as a result of some deficiencies that arise from the use of de jure and de facto variables.

Collins (2005) argues that de facto and de jure measures are both relevant in measuring the effects of financial integration. He also notes that the de facto indicators are likely to be endogenous in growth regressions, making it difficult to pin down causal effects. Also Aizenman and Noy (2006) report that de jure measures of capital account liberalization have differential effects on de facto measures of trade and financial integration. Kose, Prasad, Rogoff and Wei (2006) remarked in their study that "looking at the empirical literature, it provide little evidence of a causal relationship between financial integration and growth" Collins (1999) and Mishra, Mody and Murshid (2001), also argue that relationship between capital inflows and growth are the quality of domestic macroeconomic policies in the recipient country, the degree and rate at which capital controls are being relaxed, and the rate at which the composition of inflows is changing.

The auto regression result implied that foreign direct investment, foreign portfolio investment and credit to private sector together with the human capital development which is represented by total expenditure in health and education could not impact on the real gross domestic product. In earlier literature he has argued that certain types of capital flows such as foreign direct investment (FDI) can yield productivity gains in recipient countries directly through transfers of technology and managerial expertise. Lee (1998) finds that FDI is positively associated with growth, but only in settings with sufficient high levels of human capital, sequel to the poor human capital development in 
Nigeria.

\subsection{Conclusion/Recommendations}

It is the priorities of this study to empirically review the causality relationship between capital flow liberalization, human capital development and economic growth in Nigeria, and secondly to examine the relationship between different component of capital flow, human capital development and economic growth in Nigeria, and we found no causality existing between capital flow liberalization (dejure, and de facto measures of openness). Again the auto regression result imply that foreign direct investment, foreign portfolio investment and credit to private sector together with the human capital development which is represented by total expenditure in health and education could not impact on the real gross domestic product. This could be as a result of lack of stable and competitive macroeconomic environment, well regulated financial sector and an excellent corporate governance environment in Nigeria which will ensure high institutional quality. Mckinon (1989) affirmed the need for macroeconomic stability and prudent financial institution regulation for financial liberalisation to lead to positive outcomes. Sound fiscal and monetary policies increase the growth benefits of capital account liberalization and help avert crises in countries with open capital account. Also note that Institutional quality has received considerable attention as an important structural factor in the relation between financial openness and growth. The quality of corporate and public governance, the legal framework, the level of corruption, and the degree of government transparency can affect the allocation of resources in an economy since capital inflows make more resources available, the quality of institutions therefore matter much more for financially open economies

Finally, inferring from the empirical literature, considerable studies found positive impact of human development on economic growth (Arrow, 1962, Jones 1996, Odusola 1997). We find that investment in health and education has no impact on economic growth, this concurs with the United Nation Development Programme (UNDP) report in 2013. Therefore, in conclusion there is need for Government to address social, political and religious issues bordering the economy, if Nigeria must achieve growth.

\section{References}

Acemoglu, D., \& Johnson, S. (2005). Unbundling Institutions. Journal of Political Economy, 113(5), 949-995. http://dx.doi.org/10.1086/432166

Adams, A. (2012). Financial Openness Induced Growth and Poverty Reduction. The International Journal of Applied Economist and Finance, 5(1), 75-86.

Aizenman, J., Chinn, M.D., \& Ito, H. (2010). Surfing the Waves of Globalization: Asia and Financial Globalization in the Context of the Trilemma. NBER Working Paper 15876. Retrieved from http://www.nber.org/papers/w15876

Alfaro, L., Kalemli-Ozcan, S., \& Volosovych, V. (2008). Why doesn't capital flow from rich to poor countries? An empirical investigation. Review of Economics and Statistics, 90(2), 347-368. http://dx.doi.org/10.1162/rest.90.2.347

Arrow, K.J. (1962). The Economic Implications of Learning by Doing. Review of Economic Studies, 29(3), 155-173. http://dx.doi.org/10.2307/2295952

Arteta, C., Barry, E., \& Wyplosz, C. (2001). When Does Capital Account Liberalization Help More Than It Hurts? NBER Working Papers No.8414. Retrieved from http://www.nber.org/papers/w8414

Asadurian, T., Nnadozie, E., \& Wantcheon, L. (2006). Transfer Dependence and Regional Disparities in Nigerian Federalism. In Wallack, J. and T.N. Srinivasan (Eds.), Federalism and Economic Reforms: International Perspectives. New York, Cambridge University Press. http://dx.doi.org/10.1017/cbo9780511511004.009

Bakare, A.S. (2011). Financial Sector Liberalization and Economic Growth in Nigeria: An Empirical Study. Economic and Financial Review, 1(4), 08-16.

Barro, R., \& Lee, J. (1994). Losers and Winners in Economic Growth. Proceedings of the World Bank Annual Conference on Development Economics, 1993: Supplement to The World Bank Economic Review and The World Bank Research Observer. Bruno, Michael and Boris Pleskovic eds., Washington, D.C.: World Bank. Pp.267- 297.

Bekaert, G., Harvey, C.R., \& Lundblad, C. (2001). Does Financial Liberalization Spur Growth? NBER Working Paper No. 8245 (April), National Bureau of Economic Research, Cambridge, Mass. Retrieved from www.Sciendirect.com 
Chinn, M., \& Ito, H (2008). A New Measure of Financial Openness. Journal of Comparative Policy Analysis, 10(3), 309-322. http://dx.doi.org/10.1080/13876980802231123

Dupasquier, C., \& Osakwe, P.N. (2006). Trade Regimes, Liberalization and Macroeconomic Instability in Africa. African Trade Policy Centre (ATPC) Work in Progress No. 31. Economic Commission for Africa.

Easterly, W., \& Levine, R. (2000). It's Not Factor Accumulation: Stylized Facts and Growth Models. World Bank Economic Review, 15, 177-219. http://dx.doi.org/10.1093/wber/15.2.177

Edison, H.J., Klein, M., Ricci, L.A., \& Sløk, T. (2002). International Financial Integration and Economic Growth. Journal of International Money and Finance, 21(6), 749-76. http://dx.doi.org/10.1016/S0261-5606(02)00021-9

Eichengreen, B. (2003). Capital Flows and Crisis. The MIT Press, Cambridge.

Festus, O.A. (2006). Capital Account Liberalization in Nigeria: Problems and Prospects. Central Bank of Nigeria Economic and Financial Review, 44(4), 117-156.

Klein, M.W. (2003). Capital Account Openness and the Varieties of Growth Experience. Unpublished Working Paper 9500. NBER, Cambridge, Masscheusetts.

Klein, M.W., \& Olivei, G. (1999). Capital Account Liberalization, Financial Depth And Economic Growth. NBER Working Paper No 7384. Retrieved from https://ideas.repec.org/e/pk19.html

Kose, M.A., Prasad, E.S., Rogoff, K., \& Wei, S-J. (2009). Financial globalization: A reappraisal. IMF Staff Papers, 56(1), 8-62. http://dx.doi.org/10.1057/imfsp.2008.36

Kruger, A., \& Sonnenschein, H.S. (1967). The Terms of Trade, the Gains from Trade, and Price Divergence. International Economic Review, 8(1), 121-127. http://dx.doi.org/10.2307/2525389

Krugman, P. (1993). International Finance and Economic Development. In Alberto Glovanni (Ed.), Finance and Development: Issues and Experience (pp.11-24). Cambridge: Cambridge University Press. http://dx.doi.org/10.1017/CBO9780511983290.003

Lane, P.R., \& Milesi-Ferretti, G.M. (2007). The External Wealth of Nations Mark II: Revised and Extended Estimates of Foreign Assets and Liabilities. Journal of International Economics, 73(2), 223-250. http://dx.doi.org/10.1016/j.jinteco.2007.02.003

Lucas, R.E. (1988). On the mechanics of Economic Development. Journal of Monetary Economics, 22. http://dx.doi.org/10.1016/0304-3932(88)90168-7

Lucas, R.E. (1990). Why doesn't Capital Flow from Rich to Poor Countries? American Economic Review, 80(2), 92-96.

Mankiw, G., Romer, D., \& Weil, D. (1992). A Contribution to the Empirics of Economic Growth. Quarterly Journal of Economics, 107, 407-37. http://dx.doi.org/10.2307/2118477

Maurice, O. (2007). International Finance and Growth in Developing Countries: What Have We learned? University of California, Berkeley.

Mckinnon, R. (1989). Financial Liberalization and Economic Development: A Reassessment of Interest Rate Policies in Asia and Latin America. Oxford Review of Economic Policies, 5(4), 29-54. http://dx.doi.org/10.1093/oxrep/5.4.29

Mishra, D., Mody, A., \& Murshid, A.P. (2001). Private Capital Flows and Growth. Finance and Development, A Quarterly Magazine of IMF, 38(2), 104-110.

Oyejide, T.A. (2005). Capital Flows and Economic Transformation: A Conceptual Framework. A Paper Prepared For the $5^{\text {th }}$ CBN Annual Monetary Policy Conference, Abuja; Nov.10-11.

Paul, R.A., \& Schwindt, M. (2009). Aid, Natural Disasters and the Samaritan's Dilemma, Policy Research Working Paper 4952. http://dx.doi.org/10.1596/1813-9450-4952

Rebelo, S. (1991). Long-Run Policy Analysis and Long-Run Growth. Journal of Political Economy, 99(3), 500. http://dx.doi.org/10.1086/261764

Reinhart, C., \& Rogoff, K. (2004). Serial Default and the 'Paradox' of Rich to Poor Capital Flows. American Economic Review Papers and Proceedings, 94(2), 53-58.

Rodrik, D. (1998). Who Needs Capital Account Convertibility. Essays in International Finance, No 207. Princeton: International Finance Section, Department of Economics, Princeton University, 55-65. 
$\mathrm{php} / \mathrm{mjss} /$ article/download/4149/4059

Romer, P.M. (1986). Increasing Returns and Long Run Growth. Journal of Political Economy, 94, 1002-37. http://dx.doi.org/10.1086/261420

Romer, P.M. (1994). The Origins of Endogenous Growth. The Journal of Economic Perspectives, 8(1), 3-22. http://dx.doi.org/10.1257/jep.8.1.3

Schultz, T.P. (2002). Wage Gains Associated with Height as a Form of Human Capital. American Economic Review, Papers and Proceedings, pp.349-353. http://dx.doi.org/10.1257/000282802320191598

Senhadji, A. (2000). Sources of Economic Growth; An Extensive Growth Accounting Exercise. International Monetary Fund Staff Papers, 47(1). Washington D.C.

Soto, M. (2000). Capital Flows and Growth in Developing Countries: Recent Empirical Evidence. OECD Development Centre, Technical Papers No. 160.

Thomas, V., \& Wang, Y. (1996). "Distortion interventions and productivity growth" Is Asia Different? Economic Development and Cultural Change, 44(2), 265-288. http://dx.doi.org/10.1086/452213

World Bank. (1994). World Development Report 1993, Washington.

World Bank. (1997). Knowledge and development. Bulletin, 8(4), 1-24.

World Health Organization. (1998). Health, Health Policy and Economic Outcomes. Prepared by the Health and Development Satellite, WHO Transition Team.

Yellen, J.L. (2011). Reaping the Full Benefits of Financial Openness. Speech at the Bank of Finland $200^{\text {th }}$ Anniversary Conference, Helsinki, Finland.

Appendix. Pairwise Correlation Matrix

$\begin{array}{lccccc} & \text { RGDP } & \text { DEJU } & \text { DEFA } & \text { EXED } & \text { EXHT } \\ \text { RGDP } & 1.000000 & 0.497673 & -0.359190 & -0.283101 & -0.369648 \\ \text { DEJU } & 0.497673 & 1.000000 & -0.754901 & -0.606387 & -0.521990 \\ \text { DEFA } & -0.359190 & -0.754901 & 1.000000 & 0.910234 & 0.542900 \\ \text { EXED } & -0.283101 & -0.606387 & 0.910234 & 1.000000 & 0.265334 \\ \text { EXHT } & -0.369648 & -0.521990 & 0.542900 & 0.265334 & 1.000000\end{array}$

Pairwise Granger Causality Tests

Date: 01/06/15 Time: 14:54

Sample: 19902012

Lags: 2

\begin{tabular}{lccc}
\hline \hline Null Hypothesis: & Obs & F-Statistic & Probability \\
\hline \hline $\begin{array}{l}\text { DEJU does not Granger Cause RGDP } \\
\text { RGDP does not Granger Cause DEJU }\end{array}$ & 21 & $\begin{array}{l}1.93715 \\
0.15641\end{array}$ & $\begin{array}{l}0.17645 \\
0.85650\end{array}$ \\
\hline \hline DEFA does not Granger Cause RGDP & 21 & 0.53623 & 0.59510 \\
RGDP does not Granger Cause DEFA & & 0.59737 & 0.56208 \\
\hline \hline EXED does not Granger Cause RGDP & 21 & 0.22201 & 0.80334 \\
RGDP does not Granger Cause EXED & & 0.19176 & 0.82737 \\
\hline \hline EXHT does not Granger Cause RGDP & 21 & 0.58500 & 0.52859 \\
RGDP does not Granger Cause EXHT & $=$ & 1.75936 & 0.20387 \\
\hline \hline
\end{tabular}




\begin{tabular}{|c|c|c|c|}
\hline DEFA does not Granger Cause DEJU & 21 & 3.07512 & 0.07412 \\
\hline DEJU does not Granger Cause DEFA & & 1.91358 & 0.17984 \\
\hline EXED does not Granger Cause DEJU & 21 & 4.55206 & 0.02723 \\
\hline DEJU does not Granger Cause EXED & & 1.66065 & 0.22114 \\
\hline EXHT does not Granger Cause DEJU & 21 & 2.22274 & 0.14066 \\
\hline DEJU does not Granger Cause EXHT & & 1.88818 & 0.18356 \\
\hline EXED does not Granger Cause DEFA & 21 & 0.44296 & 0.64977 \\
\hline DEFA does not Granger Cause EXED & & 4.13338 & 0.03572 \\
\hline EXHT does not Granger Cause DEFA & 21 & 4.77743 & 0.02361 \\
\hline DEFA does not Granger Cause EXHT & & 3.24032 & 0.06584 \\
\hline EXHT does not Granger Cause EXED & 21 & 12.1087 & 0.00063 \\
\hline EXED does not Granger Cause EXHT & & 1.90760 & 0.18071 \\
\hline
\end{tabular}

Dependent Variable: D(RGDP)

Method: Least Squares

Date: 01/06/15 Time: 14:46

Sample (adjusted): 19922012

Included observations: 21 after adjustments

\begin{tabular}{crlrr}
\hline \hline Variable & Coefficient & Std. Error & t-Statistic & Prob. \\
\hline \hline C & 0.757170 & 0.356437 & 2.124276 & 0.0596 \\
RGDP(-1) & -0.337442 & 0.211138 & -1.598206 & 0.1411 \\
RGDP(-2) & -0.054052 & 0.088747 & -0.609054 & 0.5561 \\
D(DEJU) & 1.942390 & 0.894511 & 2.171454 & 0.0550 \\
D(D(FDIN)) & $-1.37 \mathrm{E}-06$ & $1.62 \mathrm{E}-06$ & -0.847638 & 0.4165 \\
D(PFIN) & $2.18 \mathrm{E}-08$ & $5.44 \mathrm{E}-07$ & 0.040173 & 0.9687 \\
D(D(CPSN)) & $-9.56 \mathrm{E}-08$ & $1.04 \mathrm{E}-07$ & -0.915904 & 0.3813 \\
D(DEBT) & $1.64 \mathrm{E}-07$ & $4.25 \mathrm{E}-07$ & 0.385454 & 0.7080 \\
D(EXED) & $-1.18 \mathrm{E}-05$ & $5.96 \mathrm{E}-06$ & -1.987254 & 0.0750 \\
D(EXHT) & $-6.67 \mathrm{E}-06$ & $5.61 \mathrm{E}-06$ & -1.188971 & 0.2619 \\
D(INSQ) & 0.007225 & 0.014574 & 0.495779 & 0.6308 \\
\hline \hline R-squared & 0.539628 & Mean dependent var & -0.005239 \\
Adjusted R-squared & 0.079257 & S.D. dependent var & 1.085619 \\
S.E. of regression & 1.041710 & Akaike info criterion & 3.225286 \\
Sum squared resid & 10.85160 & Schwarz criterion & 3.772417 \\
Log likelihood & -22.86550 & F-statistic & 1.172159 \\
Durbin-Watson stat & 2.240528 & Prob(F-statistic) & 0.403289 \\
\hline \hline
\end{tabular}




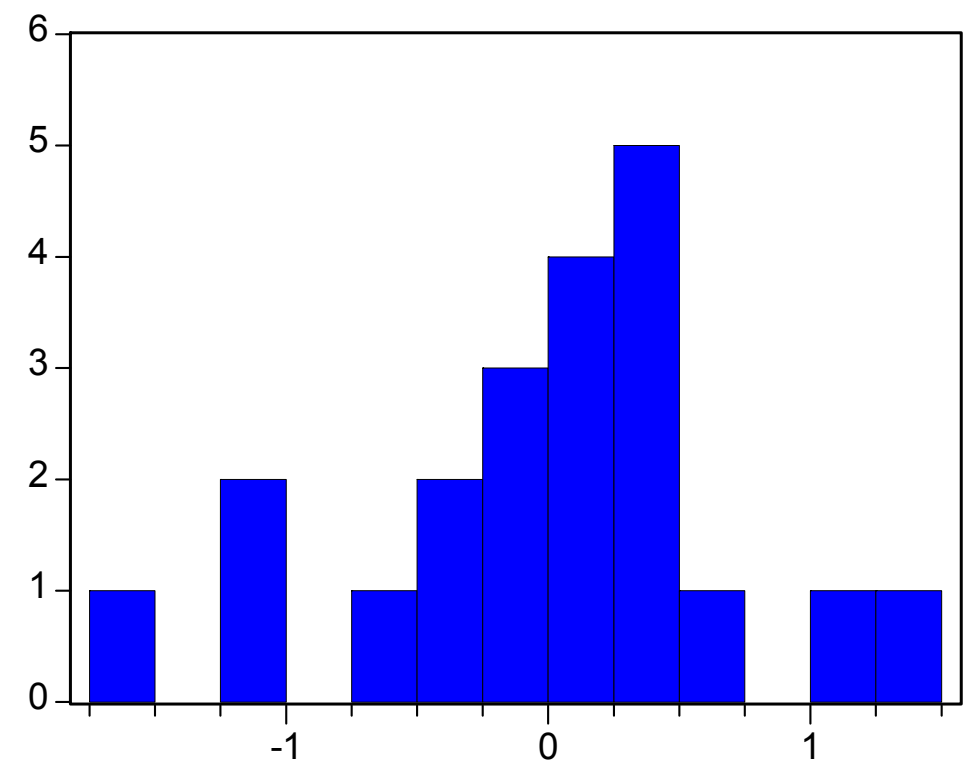

Series: Residuals

Sample 19922012

Observations 21

Mean

Median

$-1.24 \mathrm{e}-16$

Maximum

0.056034

Minimum

1.410296

Std. Dev.

$-1.575021$

Skewness

0.736600

Kurtosis

$-0.369141$

Jarque-Bera

3.076230

Probability

0.482012

0.785837

Breusch-Godfrey Serial Correlation LM Test:

\begin{tabular}{llll}
\hline \hline F-statistic & 0.611385 & Probability & 0.566128 \\
Obs*R-squared & 2.784214 & Probability & 0.248551 \\
\hline \hline
\end{tabular}

Test Equation:

Dependent Variable: RESID

Method: Least Squares

Date: 01/06/15 Time: 14:49

Presample missing value lagged residuals set to zero.

\begin{tabular}{crrrr}
\hline \hline Variable & Coefficient & Std. Error & t-Statistic & Prob. \\
\hline \hline C & -0.045760 & 0.418968 & -0.109221 & 0.9157 \\
RGDP(-1) & -0.020291 & 0.358683 & -0.056570 & 0.9563 \\
RGDP(-2) & -0.012968 & 0.093180 & -0.139167 & 0.8928 \\
D(DEJU) & -0.212339 & 0.971077 & -0.218664 & 0.8324 \\
D(D(FDIN) $)$ & $-1.85 \mathrm{E}-07$ & $1.69 \mathrm{E}-06$ & -0.109398 & 0.9156 \\
D(PFIN) & $-2.93 \mathrm{E}-07$ & $6.63 \mathrm{E}-07$ & -0.442359 & 0.6699 \\
D(D(CPSN) & $-2.19 \mathrm{E}-08$ & $1.16 \mathrm{E}-07$ & -0.189880 & 0.8541 \\
D(DEBT) & $7.04 \mathrm{E}-08$ & $4.57 \mathrm{E}-07$ & 0.154068 & 0.8814 \\
D(EXED) & $4.11 \mathrm{E}-06$ & $7.34 \mathrm{E}-06$ & 0.559976 & 0.5908 \\
D(EXHT) & $4.88 \mathrm{E}-06$ & $7.63 \mathrm{E}-06$ & 0.639166 & 0.5406 \\
D(INSQ) & -0.002893 & 0.015523 & -0.186383 & 0.8568 \\
RESID(-1) & -0.240613 & 0.573509 & -0.419546 & 0.6859 \\
RESID(-2) & 0.526435 & 0.578910 & 0.909355 & 0.3897 \\
\hline \hline R-squared & 0.132582 & Mean dependent var & $-1.24 \mathrm{E}-16$
\end{tabular}




\begin{tabular}{lrll} 
Adjusted R-squared & -1.168546 & S.D. dependent var & 0.736600 \\
S.E. of regression & 1.084716 & Akaike info criterion & 3.273528 \\
Sum squared resid & 9.412875 & Schwarz criterion & 3.920137 \\
Log likelihood & -21.37205 & F-statistic & 0.101897 \\
Durbin-Watson stat & 2.060742 & Prob(F-statistic) & 0.999682 \\
\hline \hline
\end{tabular}

Ramsey RESET Test:

\begin{tabular}{llll}
\hline \hline F-statistic & 1.151764 & Probability & 0.311111 \\
Log likelihood ratio & 2.528882 & Probability & 0.111779 \\
\hline \hline
\end{tabular}

Test Equation:

Dependent Variable: D(RGDP)

Method: Least Squares

Date: 01/06/15 Time: 14:50

Sample: 19922012

Included observations: 21

\begin{tabular}{crlrr}
\hline \hline Variable & Coefficient & Std. Error & t-Statistic & Prob. \\
\hline \hline C & 0.999962 & 0.419915 & 2.381345 & 0.0411 \\
RGDP(-1) & -0.266696 & 0.219678 & -1.214030 & 0.2556 \\
RGDP(-2) & -0.056931 & 0.088122 & -0.646041 & 0.5344 \\
D(DEJU) & 1.777526 & 0.900992 & 1.972855 & 0.0800 \\
D(D(FDIN)) & $-8.02 \mathrm{E}-07$ & $1.69 \mathrm{E}-06$ & -0.474162 & 0.6467 \\
D(PFIN) & $-1.36 \mathrm{E}-07$ & $5.59 \mathrm{E}-07$ & -0.242554 & 0.8138 \\
D(D(CPSN)) & $-9.35 \mathrm{E}-08$ & $1.04 \mathrm{E}-07$ & -0.903012 & 0.3900 \\
D(DEBT) & $-1.63 \mathrm{E}-08$ & $4.54 \mathrm{E}-07$ & -0.035829 & 0.9722 \\
D(EXED) & $-1.23 \mathrm{E}-05$ & $5.93 \mathrm{E}-06$ & -2.078907 & 0.0674 \\
D(EXHT) & $-7.00 \mathrm{E}-06$ & $5.58 \mathrm{E}-06$ & -1.255163 & 0.2410 \\
D(INSQ) & 0.019854 & 0.018646 & 1.064750 & 0.3147 \\
FITTED^2 & -0.501041 & 0.466865 & -1.073203 & 0.3111 \\
\hline \hline & & & & \\
R-squared & 0.591860 & Mean dependent var & -0.005239 \\
Adjusted R-squared & 0.093022 & S.D. dependent var & 1.085619 \\
S.E. of regression & 1.033894 & Akaike info criterion & 3.200101 \\
Sum squared resid & 9.620434 & Schwarz criterion & 3.796971 \\
Log likelihood & -21.60106 & F-statistic & 1.186477 \\
Durbin-Watson stat & 2.068827 & Prob(F-statistic) & 0.405170 \\
\hline \hline
\end{tabular}

